\begin{tabular}{c|c|c}
\hline \hline Vol. 225: 189-195, 2002 & MARINE ECOLOGY PROGRESS SERIES \\
Mar Ecol Prog Ser & Published January 11 \\
\hline
\end{tabular}

\title{
Effects of competition between two introduced Caulerpa
}

\author{
Luigi Piazzi ${ }^{1}$, Giulia Ceccherelli ${ }^{2, *}$ \\ ${ }^{1}$ Dipartimento dell'Uomo e dell'Ambiente, Università di Pisa, via A Volta 6, Pisa 56126, Italy \\ ${ }^{2}$ Dipartimento di Botanica ed Ecologia Vegetale, Università di Sassari, via F Muroni 25, Sassari 07100, Italy
}

\begin{abstract}
Competitive interactions between 2 introduced algae, Caulerpa taxifolia and C. racemosa, were studied in 2 experiments. The first separately evaluated the interspecific and intraspecific effects on both species by manipulating their abundance. The second investigated the fate of fragments of C. taxifolia transplanted into patches of C. racemosa, in contrast to those established on algal turfs. C. racemosa and C. taxifolia had similar temporal trends in growth but reached different sizes. The overall increase in stolon length at higher densities for both species suggested that positive interactions are very important. However, there was a significant interspecific effect on C. taxifolia stolon length but no effect on C. racemosa. Furthermore, C. taxifolia fragments transplanted into C. racemosa patches showed clear signs of stress with respect to those transplanted into algal turfs: blades became blanched and eroded. Overall, the results of this study suggest that growth increases with density augmentation, therefore suggesting that invasive characteristics of the species may increase with the time of colonisation. Both species tend to spread faster at higher density. Overall, where both species co-occur, we predict that C. racemosa would be the favoured species as regards the outcome of competition.
\end{abstract}

KEY WORDS: Caulerpa taxifolia $\cdot$ Caulerpa racemosa $\cdot$ Competition $\cdot$ Introduced species $\cdot$ Positive interaction Resale or republication not permitted without written consent of the publisher

\section{INTRODUCTION}

Biological introductions in marine ecosystems are widely reported and over the last years they have shown an increasing trend linked to the development of international shipping, aquaculture and aquarium activity (Carlton 1989, Carlton \& Geller 1993, Verlaque 1994, Ribera \& Boudouresque 1995). In many cases, introduced species are able not only to establish themselves but they also tend to become invasive, affecting native ecosystems (Grosholz \& Ruiz 1995, Trowbridge 1995, Abrams 1996, Reusch \& Williams 1998). The lack of natural enemies, predators or competitors, makes introduced species potential invaders. The success of invasive species is generally linked to their growth,

\footnotetext{
*Corresponding author. E-mail: cecche@uniss.it
}

reproduction and dispersal strategies together with the ability of populations to persist. In many cases, introduced species have the potential to radically alter the structure and function of native ecosystems causing a decrease of biodiversity (Vitousek 1990, Airoldi et al. 1995, Grosholz \& Ruiz 1995, Ceccherelli \& Cinelli 1997, Walker \& Kendrick 1998, Piazzi \& Cinelli 2000). When 2 or more introduced species co-occur, competitive interaction between them or synergetic deleterious effects on indigenous species could occur. One of the important goals for ecologists is to understand interactions among invasive species in order to predict possible effects on colonised communities.

Biological invasions by macroalgae are widely reported in many benthic systems (Critchley et al. 1990, Hay 1990, Sanderson 1990, Sindermann 1991, Chambers et al. 1993, Russel \& Balazs 1994, Verlaque 1994, Ribera \& Boudouresque 1995). In the Western Medi- 
terranean Sea, the successful introduction of the Caulerpa species is particularly worrying. In 1984, C. taxifolia (Vahl) C. Agardh was recorded in the Mediterranean along Monegasque coasts (Meinesz \& Hesse 1991) and since then it has quickly colonised wide areas of the Mediterranean (Boudouresque et al. 1992, 1994, Meinesz et al. 1993, 1998). C. racemosa (Forsskål) J. Agardh is considered an immigrant from the Red Sea and has been spreading for a long time in the Southeastern Mediterranean (Hamel 1926, Aleem 1948, Lipkin 1972) and recently in the Western Mediterranean (Piazzi et al. 1994, 1997, Bussotti et al. 1996, Gambi \& Terlizzi 1998, Verlaque et al. 2000).

Both species showed high invasive characteristics and caused deep modifications of benthic communities, mostly related to the decreasing species diversity (Verlaque \& Fritayre 1994, Bellan-Santini et al. 1996, Piazzi et al. 2001). Interactions between the 2 introduced species and the native flora have been experimentally investigated (Ceccherelli \& Cinelli 1997, 1999a, Ceccherelli et al. 2000). Competitive ability of the 2 congener species could be similar if this was based on plant traits (Olson \& Lubchenco 1990). Both species have stolons which are able to quickly elongate, easily overgrow other macroalgal species (Meinesz et al. 1995, Piazzi et al. 1997) and have a high potential of dispersal by fragmentation and re-establishment of stolons (Ceccherelli \& Cinelli 1998, Ceccherelli \& Piazzi 2001).

The 2 introduced species first co-occurred in the Mediterranean in a restricted area along the Tuscan coast (Piazzi et al. 1999) and, more recently, along the French coast (A. Meinesz pers. comm.). The interactions between these 2 congener algae offer a unique opportunity to investigate the competitive outcome between 2 species that have similar life strategies, growth, reproduction and physiological adaptations. This knowledge would offer an important insight into the effects of this interaction on their colonisation rate.

The aim of this work is to investigate competitive interactions between Caulerpa taxifolia and C. racemosa, simultaneously studying the effect of inter- and intraspecific competition. This has been done by separately evaluating the effect of intra- and interspecific increases in density on each of the species, and their interrelationship. To achieve these objectives, 2 reciprocal experiments (competition experiments) were performed through manipulation of the abundance of the species.

This work also aims to investigate the fate of fragments of Caulerpa taxifolia when they establish in patches of C. racemosa in contrast to when they establish on algal turfs. Fragments of $C$. taxifolia can easily re-establish after they are uprooted (Ceccherelli \& Cinelli 1999a). The C. taxifolia transplant experiment, which consists of experimental transplants of C. taxifolia in both habitats, reproduces a natural situation occurring at the site, where dense mats of C. racemosa have colonised wide surfaces, while $C$. taxifolia is distributed in smaller patches.

\section{MATERIAL AND METHODS}

Study site. The study site is located south of Leghorn $\left(43^{\circ} 28^{\prime} 24^{\prime \prime} \mathrm{N}\right.$ and $\left.10^{\circ} 19^{\prime} 42^{\prime \prime} \mathrm{E}\right)$ on an exposed shore at a depth of $10 \mathrm{~m}$. The bottom is characterised by a rocky platform colonised by a photophilous turf-dominated macroalgal assemblage, composed mainly of Womersleyella setacea Hollenberg (Airoldi et al. 1995) and patches of the marine seagrass Posidonia oceanica (L.) Delile. The study was carried out from July 1998 to September 1999.

Competition experiments. The first experiment tested the effect of intra- and interspecific competition on Caulerpa taxifolia and C. racemosa, respectively. In each experiment, transplant material consisted of fragments of $C$. racemosa and C. taxifolia bearing the stolon (10 cm long), rhizoids and blades. Each experimental unit consisted of a $20 \times 20 \mathrm{~cm}$ surface in which fragments were anchored using plastic covered metal staples (Ceccherelli et al. 2000). Transplants were done on a Posidonia oceanica dead 'mat' because it is a suitable substrate that guarantees a high success of transplantation (Ceccherelli \& Cinelli 1999b, Piazzi et al. 2001). Unfortunately extended areas at the site of Posidonia oceanica dead 'mat' were not frequent because C. racemosa had already naturally colonised many of the available areas. Furthermore, transplanting C. taxifolia fragments far from this site would not have been ethical because, unlike C. racemosa, this alga is not present in other areas in Tuscany. The poor replication used in the present experiments was thus influenced by the limited availability of substrata suitable for transplants at the site.

The controls consisted of a chosen density ( 2 fragments) of 1 species which was then compared to experimental plots with different fragment density $(2+2$ and $2+4$ fragments) of each species alone or in combination. Hence, each experiment consisted of the following 5 treatments (Table 1): (1) 2 fragments of Species A (controls), (2) 4 fragments of Species A, (3) 6 fragments of Species A, (4) 2 fragments of Species A and 2 fragments of Species B, and (5) 2 fragments of Species A and 4 fragments of Species B. In the first experiment, Species A was Caulerpa taxifolia and Species B was C. racemosa, while in the second experiment species were oppositely assigned. The comparison among Treatments 1,2 and 3 detects intraspecific interactions in each species while detection of inter- 
specific competition was evidenced by the comparison of Treatments 1, 4 and 5 (Underwood 1986, 1992, 1997). Treatments were interspersed and there were 3 replicates for each treatment spaced at about $5 \mathrm{~m}$ apart. The whole experimental area was about $250 \mathrm{~m}^{2}$.

Transplanting was undertaken in July 1998, because previous studies showed that summer is the best season to ensure transplant success of either Caulerpa taxifolia or C. racemosa (sensu Chapman 1986). Fragments of the alga, complete in portions, were manually uprooted from areas of the same depth and fixed to the substratum of experimental units within $1 \mathrm{~h}$ using 2 plastic covered metal U-shaped hooks per fragment that stapled the stolon to the substrata. All fragments were taken from the same area and we assumed that possible effects of differing initial sizes of blades and rhizoids were negligible.

The response variable used as the descriptor of rate of colonisation for the 2 algae was stolon maximum length which was measured in situ. During the study, the experimental units grew abundantly and the fragments transplanted at the beginning developed into patches of interlaced stolons. Hence, to estimate stolon growth we decided to measure the length of the longest stolon per patch, even if it was over the edges of the experimental unit. Percent cover of algae in experimental units would have been less informative if the growth of both species was fast, as just a few fragments could totally cover the local substratum (Piazzi et al. 2001). The response variable was measured 5 times (July, October 1998, January, April and September 1999). Data from the last sample were analysed by asymmetrical fixed factorial ANOVAs to determine differences among density treatments (amount of initial fragments and proportion of species). The required sums of squares for asymmetrical components of these analyses were calculated following Underwood (1992, 1993, 1997). Before running the analyses, the assumption of homogeneity of variances was examined using Cochran's test. Student-Newman-Keuls (SNK) tests were used for a posteriori multiple comparisons of means.

Caulerpa taxifolia transplant experiments. Fragments of C. taxifolia were transplanted into high density C. racemosa patches; the reverse transplants could not be done because of the sporadic occurrence of $C$. taxifolia at the site. In each experimental plot $(20 \times$ $20 \mathrm{~cm}$ ), 4 fragments of $C$. taxifolia were fixed to the substratum as described above. In the C. racemosa habitat more than 50 stolons of the alga were present, while in controls only algal turfs were present. Treatment and control experiments were replicated in triplicate in each of 2 areas randomly chosen within the study site. Stolon length and blade size of $C$. taxifolia was measured 5 times (same months as response variable measurements). Data obtained on the last sam-
Table 1. Competition experiments. Experimental treatments [1 to 10] to determine influences of inter- and intraspecific competition on blade density and stolon lengths of Caulerpa taxifolia $(\mathrm{CT})$ and C. racemosa $(\mathrm{CR})$ at different fragment densities

\begin{tabular}{|lccc|}
\hline & \multicolumn{3}{c|}{ Fragment density } \\
\cline { 2 - 4 } Control $(2)$ & $(2+2)$ & $(2+4)$ \\
\hline Caulerpa taxifolia & & & \\
CT added & {$[1]$} & {$[2]$} & {$[3]$} \\
CR added & $2 \mathrm{CT}$ & $2 \mathrm{CT}+2 \mathrm{CT}$ & $2 \mathrm{CT}+4 \mathrm{CT}$ \\
Caulerpa racemosa & & {$[4]$} & {$[5]$} \\
CR added & {$[6]$} & $\mathrm{CT}+2 \mathrm{CR}$ & $2 \mathrm{CT}+4 \mathrm{CR}$ \\
CT added & $2 \mathrm{CR}$ & $2 \mathrm{CR}+2 \mathrm{CR}$ & $2 \mathrm{CR}+4 \mathrm{CR}$ \\
& & {$[9]$} & {$[10]$} \\
& & $2 \mathrm{CR}+2 \mathrm{CT}$ & $2 \mathrm{CR}+4 \mathrm{CT}$ \\
\hline
\end{tabular}

pling date were analysed 2-way ANOVA with 'habitat' (C. racemosa vs algal turfs) treated as the fixed factor and 'area' (2 levels) as the random factor nested to 'habitat'. Cochran's test was used to test the assumption of homogeneity of variances.

\section{RESULTS}

\section{Competition experiments}

Caulerpa racemosa and C. taxifolia stolon length was greater in October 1998 and in September 1999 than the other dates for both species. From October to January C. taxifolia stolon size did not change while C. racemosa stolon length decreased (Fig. 1). Between January and April, a decrease in stolon size was recorded in C. taxifolia, while a more relevant change in stolon length was observed for C. racemosa, which regressed to smaller sizes than the ones initially recorded.

Overall, results clearly showed that stolon length increased with respect to controls. However, this effect significantly differed among treatments. Caulerpa taxifolia stolon length was significantly affected by the addition of fragments (density) depending on the species added (C. taxifolia vs C. racemosa) (Fig. 1A, Table 2). This result suggests a significant interspecific effect on stolon length of $C$. taxifolia where 4 fragments were added, since a lower stolon length was recorded where C. racemosa was present. Conversely, in the case of 2 fragments added $(2+2$ treatments) there was not a significantly different effect between species added (Table 2, SNK test). Further, where $C$. taxifolia fragments were added to fragments of the same species, a positive effect of the increase in density was found indicating a positive intraspecific inter- 

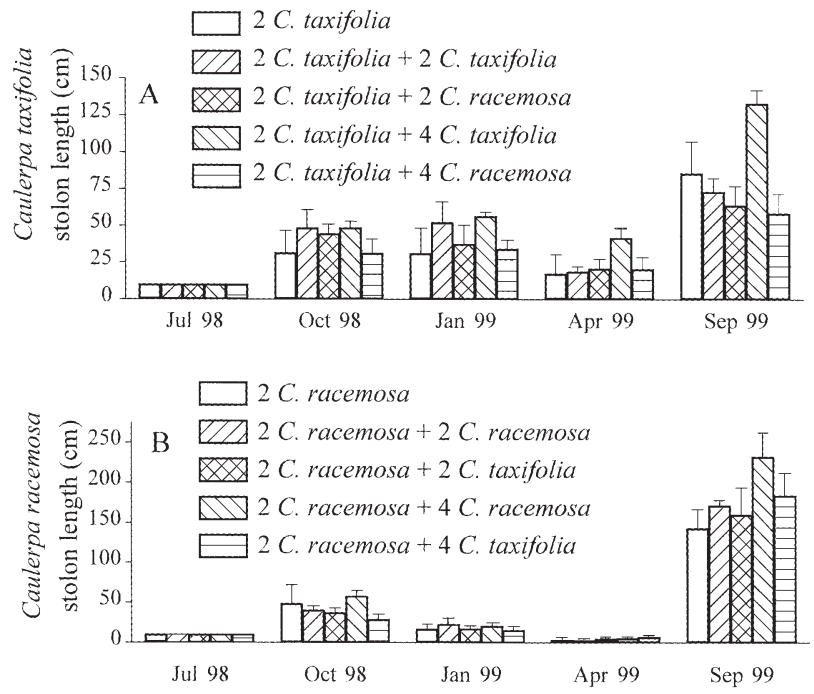

Fig. 1. Competition experiments. Temporal variation during the study period of mean $( \pm \mathrm{SE})$ stolon length of (A) Caulerpa taxifolia and (B) C. racemosa in treatments of different densities and different species added ( $\mathrm{n}=3$ replicates). Numbers reported on legend refer to fragments combinations used in treatments

action (Table 2, SNK test). Conversely, C. racemosa stolon length was found to be homogeneous among treatments: none of the factors significantly affected stolon size (Fig. 1B) and thus neither the density nor the species added.

\section{Caulerpa taxifolia transplant experiment}

Caulerpa taxifolia showed a different temporal trend between the 2 habitats both in stolon length and blade size (Fig. 2). For example, an increase in stolon length was observed during autumn 1998 on algal turfs, while a great homogeneity over time was observed in $C$. racemosa. At the end of the study period, significant differences $(\mathrm{p}<0.05)$ between habitats were detected, both in stolon length and in blade size (Fig. 2) $\left(F_{1,2}=\right.$ 292.6 and $F_{1,2}=102.1$, respectively). In September 1999, C. taxifolia stolon length was $16.7 \pm 2.1$ and $77 \pm$ $4.6 \mathrm{~cm}$ in C. racemosa habitat and on algal turfs, respectively, and blade size was $5.8 \pm 0.4$ and $20.2 \pm$ $1 \mathrm{~cm}$, respectively. No significant difference $(p>0.05)$ was found between experimental areas for both response variables, suggesting that local conditions do not affect the algal spread $\left(F_{2,8}=1.79\right.$ and $F_{2,8}=0.6$ for blade size and stolon length, respectively). Overall, C. taxifolia fragments transplanted into C. racemosa patches showed clear signals of stress in comparison to those transplanted into algal turfs: blades began to fade in color and branches reduced their length (Fig. 2) as evidenced since the first sampling date. This pattern was consistent over the study period.

\section{DISCUSSION}

Temporal patterns found for the stolon length of Caulerpa taxifolia and C. racemosa were in accordance to seasonal variations in stolon length and blade size shown in other studies for both algae in the Mediterranean (Meinesz et al. 1995, Ceccherelli \& Cinelli 1998, Piazzi \& Cinelli 1999, Ceccherelli et al. 2000). C. racemosa has stronger temporal fluctuations compared to C. taxifolia. For the former species the period of vegetative rest occurred earlier (between October and January), and during that period a more dramatic thallus reduction was found than for C. taxifolia. Despite this, C. racemosa showed greater stolon elongation than C. taxifolia, as observed in previous studies (Piazzi et al. in press), which counterbalanced the winter regression. This feature suggests that the response of the 2 species to environmental changes is quite different, contrary to the initail belief that their tolerances would be very similar as they belong to the same genus and both have tropical origins.

Although interspecific effects occurred, the overall increase in stolon length at higher densities for both species suggested that positive interactions are very important. A positive intraspecific interaction was detected for $\mathrm{Cau}$ lerpa taxifolia, suggesting that growth increases at higher densities. A similar 
pattern was found in C. racemosa even when differences among treatments were not significant. Positive intraspecific interactions have already been described for other macroalgae, which affect survival, growth and reproduction of the species. Density mostly influences plant resistance to hydrodynamism, vulnerability to grazing and dislodgement, and epiphyte growth (Schiel \& Choat 1980, Hay 1981, Padilla 1984, Reed 1990). For these introduced Caulerpa species, the exaggeration of the negative effect of hydrodynamism is likely to be the most important mechanism of interaction. Although further experimental studies would be necessary to test this hypothesis, shelter condition has already been indicated as facilitative, even if detrimental to light availability. Lower grazing pressure seems to be the least probable positive effect of the high density of Caulerpa spp. as neither are subjected to significant grazing in the Mediterranean (Boudouresque et al. 1996, Ganteaume et al. 1998).

In general, competitive interactions in seaweeds may occur through both interference and exploitation mechanisms (Carpenter 1990, Olson \& Lubchenco 1990); on the other hand, species have different competitive abilities in relation to their life-history traits (Gaudet \& Keddy 1988). The mechanisms involved in these interactions can be consumption, pre-emption, overgrowth, or through allelochemical substances (e.g., Schoener 1983, Olson \& Lubchenco 1990). The species examined in this study have very similar characteristics; they are both invasive and considered to be strong competitors (Meinesz \& Hesse 1991, de Villèle \& Verlaque 1995, Ceccherelli \& Cinelli 1997, Ceccherelli unpubl. data). They showed similar competitive characteristics based on direct interference by overgrowth (de Villèle \& Verlaque 1995, pers. obs.).

Significant interspecific effects were detected between the 2 species with the densities used in this experiment. In fact, Caulerpa racemosa strongly affected C. taxifolia stolon size (competition experiments) and blade size (C. taxifolia transplant experiment). Mechanisms that regulate this interaction still need to be investigated. Direct interactions such as overgrowth may be involved in competition between algae with similar characteristics. This type of competitive mechanism has been mostly described in nongeniculated Corallinales (Sebens 1986, Morcom et al. 1997) and turf-forming algae (Airoldi 2000). However, stoloniferous marine species may easily overgrow other benthic organisms (Verlaque \& Fritayre 1994, Piazzi et al. 1997): the interaction between 2 stoloniferous overgrowing species, such as those of this study, is likely to be very affected by the elongation rate of stolons. Due to the rapid growth and ability to form multilayer mats (Piazzi \& Cinelli 1999), C. racemosa stolons quickly overgrew stolons of $C$. taxifolia. This feature happened where
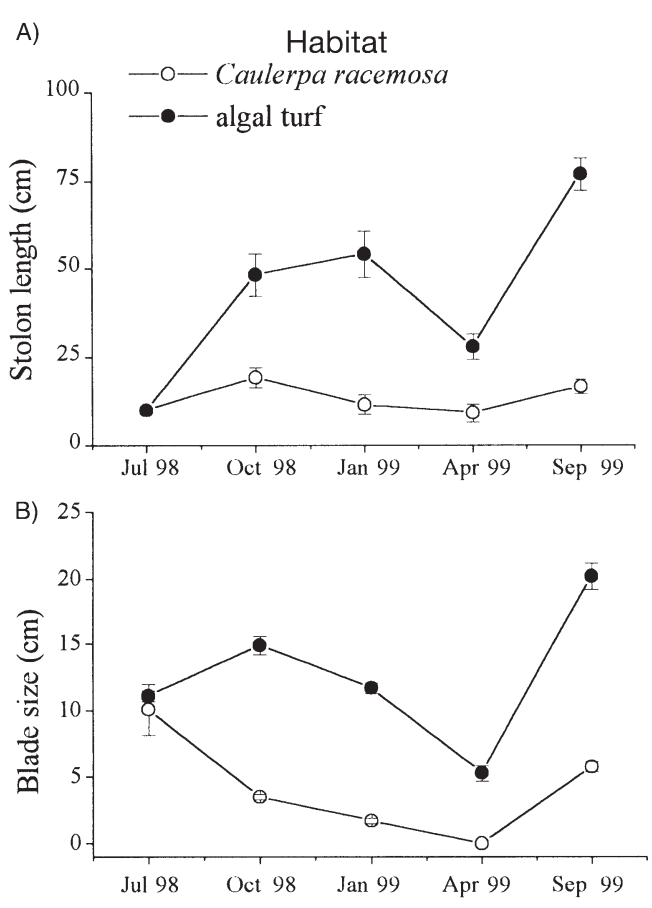

Fig. 2. Caulerpa taxifolia transplant experiment. Temporal variation during the study period of mean $( \pm \mathrm{SE})$ of $(\mathrm{A})$ Caulerpa taxifolia stolon length and (B) blade size on C. racemosa and on algal turf ( $\mathrm{n}=6$ replicates)

both species were transplanted (competition experiments) and where $C$. taxifolia was transplanted into $C$. racemosa established patches $(C$. taxifolia transplant experiment). However, aboveground characteristics of the 2 species are very different: $C$. taxifolia has a much higher canopy (8 to $9 \mathrm{~cm}$ mean) compared to C. racemosa $(\sim 2 \mathrm{~cm})$, which remained in the shade of the former. C. taxifolia canopy size prevents suffocation and shading by C. racemosa, even though the presence of C. racemosa has an effect on its blade size. Furthermore, the allelochemical mechanism of direct interaction might be involved, and in fact, the different presence of fatty acids, sterols and diterpenes among the most common species of this genus has suggested that C. racemosa and C. taxifolia are phycochemically different in many aspects (Aliya \& Shameel 1998).

Exploitative mechanisms of interaction are the least probable for these algae. Being good pioneers on unvegetated sediment (Williams 1990), they have a wide range of tolerance and are not affected by nutrient and light limitation (Chisholm et al. 1996, Delgado et al. 1996, Ceccherelli \& Cinelli 1999b). Caulerpales can uptake nutrients using rhizoids (Williams 1984), and thus nutrient availability in the sediment should affect both species since they exhibit similar rhizoid morphology (Ceccherelli \& Cinelli 1997). The fact that species blade size is different should favour the 
resource acquisition of $C$. taxifolia as this species is otherwise less advantaged from the outcome of the interaction.

Overall, the results of this study suggest that growth increases with density augmentation especially in Caulerpa taxifolia. Therefore, this result suggests that invasive characteristics of the species may increase with time of colonisation. Rate of colonisation, although initially quite high during invasion when isolated fragments establish, tends to increase at higher densities. In general, based on the interspecific effects observed, we predict that where both species co-occur C. racemosa would be the favoured species in the outcome of the competition.

Acknowledgements. We are sincerely thankful to Lisandro Benedetti-Cecchi for fruitful discussion on the statistics and Francesca Madrau for correcting the English. We are also grateful to 2 anonymous referees for the substantial revision made on the manuscript. This work was supported by a 1 yr appointment as a lecturer at the University of Sassari (Italy) to G.C. and by a research contract at the University of Pisa (Italy) to L.P. while writing the paper.

\section{LITERATURE CITED}

Abrams PA (1996) Evolution and the consequences of species introductions and deletions. Ecology 77(5):1321-1328

Airoldi L (2000) Effects of disturbance, life-histories, and overgrowth on coexistence of algal crusts and turfs. Ecology 81(3):798-814

Airoldi L, Rindi F, Cinelli F (1995) Structure, seasonal dynamics and reproductive phenology of a filamentous turf assemblage on a sediment influenced, rocky subtidal shore. Bot Mar 38:227-237

Aleem AA (1948) The recent migration of certain Indopacific algae from the Red Sea into the Mediterranean. New Phytol 47:88-94

Aliya R, Shameel M (1998) Phycochemical investigations on air-dried material of five species of Caulerpa (Bryopsidales). Bot Mar 41:125-132

Bellan-Santini D, Arnaud PM, Bellan G, Verlaque M (1996) The influence of the introduced tropical alga Caulerpa taxifolia, on the biodiversity of the Mediterranean marine biota. J Mar Biol Assoc UK 76:235-237

Boudouresque CF, Meinesz A, Verlaque M, KnoeppfflerPéeguy M (1992) The expansion of the tropical alga Caulerpa taxifolia (Chlorophyta) in the Mediterranean. Cryptogam Algol 13:144-145

Boudouresque CF, Meinesz A, Ribera MA, Ballesteros E (1994) Spread of the green alga Caulerpa taxifolia (Chlorophyta) in the Mediterranean: possible consequences of a major ecological event. Sci Mar 59(1):21-29

Boudouresque CF, Lemée R, Mari X, Meinesz A (1996) The invasive alga Caulerpa taxifolia is not a suitable diet for the sea urchin Paracentrotus lividus. Aquat Bot 53: $245-250$

Bussotti S, Conti M, Guidetti P, Martini F, Matricardi G (1996) First record of Caulerpa racemosa (Forsskål) J. Agardh along the coast of Genoa (North Western Mediterranean). Doriana 6(294):1-5

Carlton JT (1989) Man's role in changing the face of the ocean: biological invasions and implications for conservation of near-shore environments. Conserv Biol 3:265-273

Carlton JT, Geller JB (1993) Ecological roulette: the global transport of non-indigenous marine organisms. Science 261:78-82

Carpenter RC (1990) Competition among marine macroalgae: a physiological perspective. J Phycol 26:6-12

Ceccherelli G, Cinelli F (1997) Short-term effects of nutrient enrichment of the sediment and interactions between the seagrass Cymodocea nodosa and the introduced green alga Caulerpa taxifolia in the Mediterranean bay. J Exp Mar Biol Ecol 217:165-177

Ceccherelli G, Cinelli F (1998) Habitat effect on spatio-temporal variability of size and density of the introduced alga Caulerpa taxifolia. Mar Ecol Prog Ser 163:289-294

Ceccherelli G, Cinelli F (1999a) The role of vegetative spreading in dispersal of the invasive alga Caulerpa taxifolia in the Mediterranean. Mar Ecol Prog Ser 182:299-303

Ceccherelli G, Cinelli F (1999b) Effects of Posidonia oceanica canopy on Caulerpa taxifolia size in a north-western Mediterranean bay. J Exp Mar Biol Ecol 240:19-36

Ceccherelli G, Piazzi L (2001) Dispersal of Caulerpa racemosa fragments in the Mediterranean: lack of detachment time effect on establishment. Bot Mar 44:209-213

Ceccherelli G, Piazzi L, Cinelli F (2000) Response of the nonindigenous Caulerpa racemosa (Forsskål) J. Agardh to the native seagrass Posidonia oceanica (L.) Delile: effect of density of shoots and orientation of edges of meadows. J Exp Mar Biol Ecol 243:227-240

Chambers PA, Barko JW, Smith CS (1993) Evaluation of invasions and declines of submersed aquatic macrophytes. J Aquat Plant Manag 31:218-220

Chapman MG (1986) Assessment of some controls in experimental transplants of intertidal gastropods. J Exp Mar Biol Ecol 103:181-201

Chisholm JRM, Dauga C, Ageron E, Grimont PAD, Jaubert JM (1996) 'Roots' in mixotrophic algae. Nature 381:382

Critchley AT, Farnham WF, Yoshida T, Norton TA (1990) A bibliography of the invasive alga Sargassum muticum (Yendo) Fensholt (Fucales, Sargassaceae). Bot Mar 33: $551-562$

Delgado O, Rodrìguez-Prieto C, Gacia E, Ballesteros E (1996) Lack of severe nutrient limitation in Caulerpa taxifolia (Vahl) C. Agardh, an introduced seaweed spreading over oligothophic northwestern Mediterranean. Bot Mar 39: 61-67

de Villèle X, Verlaque M (1995) Changes and degradation in a Posidonia oceanica bed invaded by the introduced tropical alga Caulerpa taxifolia in the north western Mediterranean. Bot Mar 38:79-87

Gambi MC, Terlizzi A (1998) Record of large population of Caulerpa racemosa (Forsskål) J. Agardh (Chlorophyceae) in the Gulf of Salerno (Southern Tyrrhenian Sea, Italy). Biol Mar Medit 5(1):553-556

Ganteaume A, Gobert J, Malestroit P, Ménager V, Francour P, Boudouresque CF (1998) In vitro consumption of Caulerpa taxifolia (Chlorophyta) by accustomed and non-accustomed Paracentrotus lividus (echinoid): seasonal variations. J Mar Biol Assoc UK 78:239-248

Gaudet CL, Keddy PA (1988) A comparative approach to predicting competitive ability from plant traits. Nature 334: $242-243$

Grosholz ED, Ruiz GM (1995) Spread and potential impact of the recently introduced European green crab, Carcinus maenas, in central California. Mar Biol 122:239-247

Hamel G (1926) Quelques algues rares ou nouvelles pour la flore méditerranéenne. Bull Mus Nat His Nat 32(6):420 
Hay CH (1990) The dispersal of sporophytes of Undaria pinnatifida by coastal shipping in New Zealand, and implications for further dispersal of Undaria in France. Br Phycol J 25:301-313

Hay ME (1981) The functional morphology of turf-forming seaweeds: persistence in stressful marine habitats. Ecology 62:739-750

Lipkin Y (1972) Contribution to the knowledge of Suez canal migration. Marine algal and sea-grass flora of the Suez canal. Isr J Zool 21:405-446

Meinesz A, Hesse B (1991) Introduction et invasion de l'algue tropicale Caulerpa taxifolia en Méditerranée nord-occidentale. Oceanol Acta 14(4):415-426

Meinesz A, de Vaugelas J, Hesse B, Mari, X (1993) Spread of the introduced tropical green alga Caulerpa taxifolia in northern Mediterranean waters. J Appl Phycol 5:141-147

Meinesz A, Benichou L, Blanchier J, Komatsu T, Lemée R, Molenaar H, Mari X (1995) Variations in the structure, morphology and biomass of Caulerpa taxifolia in the Mediterranean. Bot Mar 38:499-508

Meinesz A, Cottalorda JM, Chiaverini D, Cassar N, De Vaugelas J (1998) Suivi de l'invasion de l'algue tropicale Caulerpa taxifolia en Méditerranée: situation au 31 Décembre 1997. Laboratoire Environnement Marin Littoral, Université de Nice-Sophia Antipolis, LEML-UNSA

Morcom NF, Ward SA, Woelkerling WJ (1997) Competition of epiphytic nongeniculate corallines (Corallinales, Rhodophyta): overgrowth is not a victory. Phycologia 36:468-471

Olson AM, Lubchenco J (1990) Competition in seaweeds: Linking plant traits to competitive outcomes. J Phycol 26: $1-6$

Padilla DK (1984) The importance of form: differences in competitive ability, resistance of consumers and environmental stress in an assemblage of coralline algae. J Exp Mar Biol Ecol 79:105-127

Piazzi L, Cinelli F (1999) Développement et dynamique saisonnière d'un peuplement méditerranéen de l'algue tropicale Caulerpa racemosa (Forsskål) J. Agardh. Cryptogam Algol 20:295-300

Piazzi L, Cinelli F (2000) Effects of the spread of the introduced Rhodophyceae Acrothamnion preissii and Womersleyella setacea on the macroalgal community of Posidonia oceanica rhizomes in the Western Mediterranean sea. Cryptogam Algol 21(3):291-300

Piazzi L, Balestri E, Cinelli F (1994) Presence of Caulerpa racemosa in the North-Western Mediterranean. Cryptogam Algol 15:183-189

Piazzi L, Balestri E, Magri M, Cinelli F (1997) Expansion de l'algue tropicale Caulerpa racemosa (Forsskål) J. Agardh (Bryopsidophyceae, Chlorophyta) le long de la côte toscane (Italie). Cryptogam Algol 18:343-350

Piazzi L, Ceccherelli G, Cinelli F (1999) Interaction between the two invasive tropical algae Caulerpa taxifolia and Caulerpa racemosa in the Mediterranean. second European Phycological Congress, 20-26 September, Montecatini Terme, Italy

Piazzi L, Ceccherelli G, Cinelli F (2001) Threat to macroalgal diversity: effects of the introduced green alga Caulerpa racemosa in the Mediterranen. Mar Ecol Prog Ser 210: 149-159

Piazzi L, Balata D, Ceccherelli G, Cinelli F (in press) Spread of the two co-occurring introduced green algae Caulerpa taxifolia and Caulerpa racemosa in the Western Mediterranean. Cryptogam Algol

Reed DC (1990) An experimental evaluation of density dependence in a subtidal algal population. Ecology 71(6): 2286-2296

Editorial responsibility: Otto Kinne (Editor), Oldendorf/Luhe, Germany
Reusch TBH, Williams SL (1998) Variable responses of native eelgrass Zostera marina to a non-indigenous bivalve Musculista senhousia. Oecologia 113:428-441

Ribera M, Boudouresque CF (1995) Introduced marine plants, with special reference to macroalgae: mechanisms and impact. In: Round FE, Chapman DJ (eds) Progress in phycological Research, Vol 11. Biopress Ltd, Bristol, p 187-268

Russell DJ, Balazs GH (1994) Colonisation by the alien marine alga Hypnea musciformis (Wulfen) J. Ag. (Rhodophyta: Gigartinales) in the Hawaiian Islands and its utilization by the green turtle, Chelonia mydas L. Aquat Bot 47: $53-60$

Sanderson JC (1990) A preliminary survey of the distribution of the introduced macroalga, Undaria pinnatifida (Harvey) Suringer on the East coast of Tasmania. Bot Mar 33: 153-157

Schiel DR, Choat JH (1980) Effects of density on monospecific stands of marine algae. Nature 285:324-326

Schoener TW (1983) Field experiments on interspecific competition. Am Nat 122:240-285

Sebens KP (1986) Spatial relationships among encrusting marine organisms in the New England subtidal zone. Ecol Monogr 56:73-96

Sindermann CJ (1991) Case histories of affects of transfers and introduction on marine resources-introduction. J Cons Int Exp Mer 47:377-378

Trowbridge CD (1995) Establishment of the green alga Codium fragile ssp. Tomentosoides on New Zealand rocky shores: current distribution and invertebrate grazers. J Ecol 83:949-965

Underwood AJ (1986) The analysis of competition by field experiments. In: Kikkawa J, Anderson DJ (eds) Community ecology: pattern and process. Blackwells, Melbourne, p 240-268

Underwood AJ (1992) Competition and marine plant-animal interactions. In: John DM, Hawkins SJ, Price JH (eds) Plant-Animal interactions in the Marine Benthos, Systematic association special, Vol 46. Clarendon Press, Oxford, p 443-475

Underwood AJ (1993) The mechanics of spatially replicated sampling programmes to detect environmental impacts in a variable world. Aust J Ecol 18:99-116

Underwood AJ (1997) Experiments in ecology. Their logical design and interpretation using analysis of variance. Cambridge University Press, Cambridge

Verlaque M (1994) Inventaire des plantes introduites en Méditerranée: origines et répercussions sur l'environnement et les activités humaines. Oceanol Acta 17:1-23

Verlaque M, Fritayre P (1994) Modifications des communautés algales méditerranéennes en présence de l'algue envahissante Caulerpa taxifolia (Vahl) C. Agardh. Oceanol Acta 17:659-672

Verlaque M, Boudouresque CF, Meinesz A, Gravez V (2000) The Caulerpa racemosa Complex (Caulerpales, Ulvophyceae) in the Mediterranean sea. Bot Mar 43:49-68

Vitousek PM (1990) Biological invasions and ecosystem processes: towards an integration of population biology and ecosystem studies. Oikos 57:7-13

Walker DI, Kendrick GA (1998) Threats to macroalgal diversity: marine habitat destruction and fragmentation, pollution and introduced species. Bot Mar 41:105-112

Williams SL (1984) Uptake of sediments ammonium and translocation in a marine green macroalga Caulerpa cupressoides. Limnol Oceanogr 29:374-379

Williams SL (1990) Experimental studies of Caribbean seagrass bed development. Ecol Monogr 60(4):449-469

Submitted: December 2, 2000; Accepted: June 7, 2001

Proofs received from author(s): January 2, 2002 